\title{
IAMJ
}

INTERNATIONAL AYURVEDIC MEDICAL JOURNAL

Case Report

ISSN: 23205091

Impact Factor: 5.344

\section{MANAGEMENT OF PAKSHAGHATA THROUGH AYURVEDA - A CASE REPORT}

\section{$\underline{\text { Nishu Raina }}$}

Assistant Professor, Department of Kayachikitsa D.A.C, Jalandhar, Punjab, India

Corresponding Author: nishu.raina2010@gmail.com

https://doi.org/10.46607/iamj16p4062020

(Published online: September 2020)

Open Access

(C) International Ayurvedic Medical Journal, India 2020

Article Received: 12/09/2020 - Peer Reviewed: 19/09/2020 - Accepted for Publication: 20/09/2020

Check for updates

\section{ABSTRACT}

Stroke is a common medical emergency and is the second leading cause of death worldwide. In Ayurveda stroke is described as Pakshaghata. The present study is a case report on management of stroke of a male patient aged 65 years with chief complaints of loss of function of the right upper \& lower limb. He was a diagnosed case of stroke on the basis of clinical presentation and brain computed tomography-scan. The case treated with the Ayurveda medications was found to be effective in providing relief in chief complaints with improvement of overall health of the patient. Treatment protocol was Snehana, Swedana, Mriduvirechana, Basti karma, Shirodhara, Nasya along with internal medications. Before treatment NIH-Stroke Scale was 16 \& Barthel index scale was 12 and after the treatment NIH-Stroke Scale was $4 \&$ Barthel index scale was 70 providing symptomatic relief too. This reveals that Ayurveda treatment modalities can play a significant role in treatment of Stroke (Pakshaghata).

Keywords: Virechana, Snehana, Svedana, Basti Karma, Shirodhara, Abhyanga, Nasya, Pakshaghata

\section{INTRODUCTION}

Stroke is defined as sudden onset of focal neurological deficit which mainly occurs due to lack of oxygen resulting from disease of cerebral vasculature and its contents resulting in loss of blood flow to the brain ${ }^{1}$. Stroke represent $3^{\text {rd }}$ most common cause of death in developed countries with prevalence of about 200 per 1 lakh persons ${ }^{2}$ and $9.94 \%$ of total deaths patients with stroke present with symptoms of sudden weakness of face, arm or leg (either on one side of the body or both) followed by other symptoms like difficulty in 
speaking, dizziness, in seeing with one or both eyes, loss of coordination, severe headache and unconsciousness. About $1 / 5$ of the patients with an acute CVA die within a month of the event and at least half those who survive are left with physical disability. Stroke can be correlated with the disease Pakshaghata in Ayurveda, where "Paksha" denotes either half of the body and "Aghata" stands for the impairment of the Karmendriyas, Gyanendriyas and Manha. When we talk about Gyanendriya, these constitute an important part of the sensory system, while on the other hand Karmendriyas denote an important part of the motor system. Manha is the one that have control on both these Gyan and Karmendriyas. Maha Vatavyadhi can manifest itself either because of Dhatu Kshaya Or Magavarana ${ }^{3}$.Stroke occurs due to disturbance in blood supply to the brain either due to lack of blood flow or haemorrhage. Basically when we talk about blood supply to the brain, the middle cerebral artery divides into the right and left middle cerebral artery and this left MCA which supplies blood to a large side of the right side of the brain gets further divided into smaller artery branches. This shows how the importance of the clinical manifestations are totally going to rely upon the type of artery or its branch, where blockage is present.

Panchakarma along with medications is very useful in treating Paralysis ${ }^{4}$. Keeping this in view, the present study was planned to assess the efficacy of stroke with medicines along with Panchakarma therapy.

Case History: A 65-year-old male K/C/O HTN /Chain smoker came to our hospital with complaints of weakness of the right side of his body including his face and was unable to walk for the last 3 months. The patient was previously diagnosed of left MCA infarct and even after taking allopathic medicines for htn, his blood pressure continued to be more on higher sides.

History: In November 2018 a patient observed a sudden dribbling of water from his mouth while drinking water followed by slight deviation of angle of mouth, slurred speech, weakness in right upper and lower limb and inability to stand and walk, dizziness. $\mathrm{He}$ was admitted at an allopathic hospital and was diagnosed as a case of CVA and treatment was given accordingly. But the patient didn't get any satisfactory relief, so he decided to move on Ayurvedic treatment from 03.05. 2019 and was discharged on 03.01.2020. And on the day of admission the patient although was conscious but with little bit drowsiness, responding to stimulation and responding to oral commands. His BP was 160/90, temperature 98.5-degree Fahrenheit, with only flickering movements observed in right limb (power) $1 / 5$ and unaffected left limb power $5 / 5$ and Constipation for 7 days. Haematological and biochemical investigations reports were within normal limits and new past history of head injury, hypertension or dyslipidemia could be elicited.

H/o Present Illness: - 65 yrs old male patient, k/c/o HTN with right CVA came to our hospital in conscious state but with little bit drowsiness and was responding to stimulation and oral commands. Patient presented with c/o weakness of the right side of his body including slight deviation of angle of mouth, slurred speech and dizziness. He was unable to stand and walk since the last 6 months (Nov. 2018) prior to admission. Patient was also suffering from itching and constipation for the last one week. He had swelling in his right lower leg and feet for the last 1 month.

\section{Examination:}

Nervous System: Conscious with little drowsiness Mental status MMSE score - 16

Table 1: Motor examination

1) Tone of muscles- Diminished (right upper \& lower limb)

2) Power of muscles- Grade - I (right upper \& lower limb)

3) Reflexes (superficial)- Swallowing - difficulty

4) Deep Reflexes

a) Rt. biceps jerk reflex - grade - 0

b) Rt. supinator jerk reflex - grade -0

c) Rt. knee jerk reflex - grade -1

d) Rt. planter jerk reflex - grade - 3 
Table 2: Assessment scale (NH Scale) (range of score-42(signifies severe stroke), BT score- 18, AT score-4)

\begin{tabular}{|c|c|c|}
\hline 1) & Level of consciousness & (Range of score $0-3)-2(\mathrm{BT})-0(\mathrm{AT})$ \\
\hline 2) & LOC questions & (Range of score $0-2)-2(\mathrm{BT})-0(\mathrm{AT})$ \\
\hline 3) & Motor arm/leg & (Range of score $0-4)-3(\mathrm{BT})-0(\mathrm{AT})$ \\
\hline 4) & limb ataxia & (Range of score $0-2)-0(\mathrm{BT})-0(\mathrm{AT})$ \\
\hline & Sensory & (Range of score $0-2)-1(\mathrm{BT})-0(\mathrm{AT})$ \\
\hline & LOC commands & -(Range of score $0-2)-1(\mathrm{BT})-0(\mathrm{AT})$ \\
\hline 7) & Visual & (Range of score $0-2)-0(\mathrm{BT})-0(\mathrm{AT})$ \\
\hline 8) & Facial paralysis & (Range of score $0-3)-1(\mathrm{BT})-1(\mathrm{AT})$ \\
\hline & Best language & (Range of score $0-3)-2(\mathrm{BT})-1(\mathrm{AT})$ \\
\hline & Dysarthia & (Range of score $0-2)-2(\mathrm{BT})-1(\mathrm{AT})$ \\
\hline
\end{tabular}

Table 3: Barthes index for Stroke Patient

\begin{tabular}{|c|c|c|c|c|}
\hline s.no & Domain name & Range of score & BT & AT \\
\hline 1 & Feeding & $\begin{array}{l}0=\text { unable } \\
5=\text { needs help in cutting, spreading butter, etc. } \\
10=\text { independent }\end{array}$ & 6 & 10 \\
\hline 2 & Bathing & $0=$ dependent $5=$ independent (or in shower) & 0 & 5 \\
\hline 3 & Grooming & $\begin{array}{l}0=\text { needs to help with personal care } \\
5=\text { independent face } / \text { hair/teeth/shaving }\end{array}$ & 0 & 0 \\
\hline 4 & Dressing & $\begin{array}{l}0=\text { dependent } \\
5=\text { needs help but can do about half unaided } \\
10=\text { independent }\end{array}$ & 0 & 5 \\
\hline 5 & Bowel & $\begin{array}{l}0=\text { incontinent (or needs to be given enemas) } \\
5=\text { occasional accident } \\
10=\text { continent }\end{array}$ & 0 & 10 \\
\hline 6 & Bladder & $\begin{array}{l}0=\text { incontinent } \text { or catheterized and unable to manage alone } \\
5=\text { occasional accident } \\
10=\text { continent }\end{array}$ & 0 & 10 \\
\hline 7 & Toilet use & $\begin{array}{l}0=\text { dependent } \\
5=\text { needs some help, but can do something alone } \\
10=\text { independent (on and off, dressing, wiping) }\end{array}$ & 0 & 5 \\
\hline 8 & Transfers (bed to chair \& back) & $\begin{array}{l}0=\text { unable, no sitting balance } \\
5=\text { major help (of one or two people, physical) can sit } \\
10=\text { minor help (verbal or physical) } \\
15=\text { independent }\end{array}$ & 5 & 10 \\
\hline 9 & Mobility (on level surface) & $\begin{array}{l}0=\text { immobile or }<50 \text { yards } \\
5=\text { wheelchair independent, including corners, }>50 \text { yards } \\
10=\text { walks with help of one person (verbal or physical) }>50 \text { yards } \\
15=\text { independent (but may use any aid; for example, stick) }>50 \text { yards }\end{array}$ & 3 & 10 \\
\hline 10 & Stairs & $\begin{array}{l}0=\text { unable } \\
5=\text { needs help (verbal, physical, carrying aid) }\end{array}$ & 0 & 5 \\
\hline & Total & & 12 & 70 \\
\hline
\end{tabular}


Table 4: Asthvidha Pariksha

1. Nadi (Pulse)-Pulse completely absent on right side, and normal (left side)@72/min, Manduka gati

2. Mootra (Urine)- Prakruta (6-7time/day, 2 time/night)

3. Malam (Fecal matter)- Malavasthamba

4. Jihwa (Tongue)- Shwetabh

5. Sabdam (Voice of patients)- slurred speech, Alipta, Jiwhakampa

6. Sparsham (Touch)- sheetasparsha (rt side both upper and lower extremity)

7. Druk (Eyes \& Vision)- Prakruta (left side), slight ptosis on right side

8. Akriti (General body build)- Madhyama

\section{Objective Findings:}

CVA was diagnosed by medical history and clinical examination. CT head shows ill-defined hypodensities involving left fronto temporal and parieto occipital origin with loss of grey white matter differentiation which in turn is suggestive of acute infarct. Chronic infarcts mostly involve bilateral occipital.

EEG showed an abnormal graph showing evidence of neural hyper excitation- low amplitude wave forms seen in all the leads bilaterally.

Table 5: Subjective Findings (symptoms of Pakshaghata)-

\begin{tabular}{|l|l|l|}
\hline 1$)$ & Vama Sandhibandhan Vimokshyana - & Absent - - (BT-0)-(AT-0)- (AF-0) \\
\hline 2) & Dakshida Sandhibandhan Vimokshyana- (Weakness of joints) & Present - (BT-8)-(AT-4)- (AF-3) \\
\hline 3$)$ & Cheshta Nivritti (Motor Activity impairment) & Present - - (BT-8)-(AT-3)- (AF-0) \\
\hline 4$)$ & Ruja (Pain) & Present-- (BT-6)-(AT-2)- (AF-0) \\
\hline 5$)$ & Vaka stambha (Slurred speech) & Present-- (BT-8)-(AT-2)- (AF-1) \\
\hline 6$)$ & Akarmandyam & Present-- (BT-6)-(AT-2)- (AF-1) \\
\hline 7$)$ & Achetnam & Absent-- (BT-0)-(AT-0)- (AF-0) \\
\hline
\end{tabular}

$* * 0=$ No pain, $1-3=$ mild pain, $4-5=$ moderate pain, $6-7=$ severe.

\section{Treatment}

Initially Patra Pinda Swedana, followed by Shirodhara, Pradhamana Nasya and Matrabasti was done along with medications. The subject was discharged on 09.01. 2020 and internal medicines were prescribed for the period of one month.

\section{DISCUSSION}

The subject is of medium build having Madhyama Bala, Avarsatva (poor mental strength), and Avara JeernaShakti (reduced digestion power). Hence Shodhana line of treatment was not followed. Some Lakshana's like Vibandha (constipation), Agnisaada (poor digestive capacity) and Aantrakujana (borborygmi) were seen ${ }^{5}$. Based on these features' treatment aiming at Ama Pachana and Pittashamana was given. Initially Sarvanga Parisheka with Panchavalkala Kashaya was given. Panchavalkala Kashaya has Ruksha, Kapha, Pitta, Shothahara, and Shitaguna and has willed healing property ${ }^{6}$. Bramhiadhi Kwatha is used for Shirodhara, which is also Vata Pitta Hara. It improves memory, speech, and intelligence and gives strength to the head and sense organs ${ }^{7}$. Pradhmananasya with Vacha Churna initially and then with Ksheerabala oil was used to restore consciousness levels ${ }^{9}$. When the symptoms of drowsiness and heaviness of the body had reduced, there was an increase in the digestion power, and he began responding to oral commands. Later Ksheerbala oil Matra Basti 40 $\mathrm{ml}$ and Sarvanga Abhyanga with Mahanarayana Taila followed by Shastikashali Mashapinda Sweden was advised. This is a kind of Sweda that makes the body supple, removes stiffness of joints vitiated by Vatadosha, cleanses the Srotas of the body, improves blood circulation, removes sluggishness of the body and is also Balya ${ }^{10}$ Ksheerabala oil Prathimarshanasya was advised in the evening to pacify Vatadosha.

Besides Panchkarma, principle of using Shamana therapy side by side, is to normalize and maintain the 
equilibrium of all the Doshas. Pakshaghata is a disease caused by Shudha Vataja condition and will show gradual onset as Vata has to vitiate in, step by step through Sanchaya, Prakopa etc, whereas that caused by Aavarana will show sudden onset and can be taken as Aavaranaa Janya. The subject is of medium built having Madhyama Bala, Avarsatva (poor mental strength), and Avara JeernaShakti (reduced digestion power). So, with ania somnifera was used for generalized weakness and to improve speed and lower limb muscular strength and neuro-muscular coordination $^{12}$. Ashwagandha churna along with Bala churna was used to help patients maintain proper nourishment of his muscle and bone, while supporting the proper function of the adrenals and reproductive system. Ashwagandha, an Indian ginseng, works as an excellent immune booster that nourishes and rejuvenates the nervous system. Dasamoolarishtam was also used because of its Ushna Veerya property and Vatahara drugs used in this formulation, that helps to pacify Vata Dosha. Rasnadi Swarasa was used as Anupana because Rasna Vatahranam Shrestham Saraswatha Churna was also used due to its Medhya and Branghana property, as it also pacifies the Vata Dosha. Besides them, Brihatvata Chintamani Rasa, Ekangveer Rasa and Rajat Bhasma were also used during the treatment, as all of them are potent Vata Shamak Dravya and best nerve stimulant due to their ingredients. Besides them, Punarnavadi Guggulu, and Shiva Gutika were also used during the treatment, just because of their Vatahara and Branghana property. After a period of 3 months, the subject started walking with support initially, and then after a period of 6 months, from the date of admission, the subject started walking without support and was recovered almost fully.

\section{CONCLUSION}

This case study demonstrates the successful management of a case of Pakshaghata that occurred mainly because of middle cerebral artery infarct and was cured through Ayurvedic treatment. Although the scope for further research and clinical trials is enormous but with the help of proper diagnosis and selec- tion of treatment protocol, Ayurveda can be enormously beneficial in the treatment of Pakshaghata. Uncommon nature of the presentation and complete recovery of the patient over the span of eight months makes this case worth documenting.

\section{REFERENCES}

1. Walter Johnson, Oyere Onuma, Mayowa Owolabi \& Sonal Sachdev. Bulletin of the World Health Organization 2016.

2. Munjal YP API textbook of medicine vol-2, $9^{\text {th }}$ edition, New Delhi jaypee brothers' medical publishers(p) ltd. 2012, p-1401.

3. Agnivesha, Charaka, Dridabala, Charak Samhita, ChikitsaSthanaVataVyadhiChikistitamAdyaya, Chapter 28, verse 59. edited by Vaidya Yadavji Trivikram aji Acharya. Chaukhambha Prakashan, Varanasi 2013, p619.

4. Prasad Mamidi Shyam Gupta, role of stroke unit care with Panchkarma in the management of stroke. An observational case series.int.j.res.Ayurveda pharma 2014:5(3):252-255, http://dx.doi.org/10.7897/2277.4343.05351.

5. Vagbhata Acharya, Ashtanga Hrudaya, Uttar Astana, Unmada, PratishedaniyaAdyaya.Chapter 6, verse 23, edited by dr Anna Moreshwar Kunte and dr Krishna Shastri Navare, Chaukhambha Samskruta Samsthana, Varanasi p 516.

6. Bhava Mishra, Bhavapraksha Samhita, Vatadivarga, edited by Brahma Shankara Mishra, c.s.s, varanasi, p:516

7. Vaghbat Acharya, Ashtanga Hrudaya, Uttar Astana, Unmada, PratishedaniyaAdyaya. Chapter 6, verse 2326, edited by Dr Anna Moreshwar Kunte and dr Krishna Shastri Navare, Chaukhambha Samskruta Samsthana, Varanasi $\mathrm{p} 799$.

8. Acharya Sharangdhar, Sharangdhara Samhita, Uttarakanda, chapter 8 , verse 22 edited by Brahmanand Tripathi, Choukhambha Sourbharti Prakashana Varanasi 2004, p375

9. Acharya Bhava Mishra, Bhavprakash Samhita, vol 2, Madhyamakanda, Shwas Rogadhikar, chapter 14, verse 51, edited by Pandit Brahma Shankar Mishra. c.s. Bhawan 2013, p166.

10. Pari Vasant c. Principles and practice of Panchakarma, $1^{\text {st }}$ edition, c.p, New Delhi p206-210. 
11. World Health Rankings - The top 20 Causes of Death in India. http://www.worldlifeexpectancy.com/indiastroke.

12. Sandhu JS - Effects of Withania somnifera (Ashwagandha) and Terminalia Arjuna (Arjuna) on physical performance and cardiorespiratory endurance in healthy young adults.

\section{Source of Support: Nil}

\section{Conflict of Interest: None Declared}

How to cite this URL: Nishu Raina: Management Of Pakshaghata Through Ayurveda - A Case Report. International Ayurvedic Medical Journal \{online\} 2020 \{cited September, 2020\} Available from: http://www.iamj.in/posts/images/upload/2543_2548.pdf 